\title{
Inter Specific Genetic Diversity within the Ethnomedicinally Important Ipomoea L. Species through Morphological and Biochemical Profiling
}

\author{
Noor Muhammad ${ }^{1,2 *}$, Nisar Uddin ${ }^{2}$, M Khalil Ullah Khan ${ }^{2}$ and Niaz Ali ${ }^{2}$ \\ ${ }^{1}$ College of Horticulture, Hebei Agricultural University, China \\ ${ }^{2}$ Department of Botany, Hazara University Mansehra, KP
}

Submission: April 15, 2019; Published: May 17, 2019

*Corresponding author: Noor Muhammad, College of Horticulture, Hebei Agricultural University, Baoding, China \& Department of Botany, Hazara University Mansehra, KP, Pakistan

\begin{abstract}
The present study has attempted to highlight the medicinal importance as well as genetic relationships among of Ipomoea species growing in Swat Valley, KP, Pakistan. There was a general agreement among the informers regarding the medicinal uses of plants and Informants Consensus Factor (ICF) value ranged from 0.991 to 0.965 . The study shown that most of the informants agreed in the application of $I$. hederacea to use as blood purifier (ICF 0.991 ) that exhibited the highest fidelity level (100\%). The intra and inter specific dissimilarity among the 28 genotypes of Ipomoea species viz., 14 genotypes of I. hedracea, 14 of I. purpurea, were tested using morphometric and biochemical profiling. Twenty-four morphological characters were counted for the assessment of intra and inter genetic disagreement through traits similarity index and cluster analysis. Total seed protein profiling was carried out on $12 \%$ slab gel electrophoresis; 6 reproducible bands were detected in both I. Purpurea and I hedracea with molecular weight ranging from 10KDa to $180 \mathrm{KDa}$. Intra locus contribution toward the genetic disagreement was $33.33 \%$ in $I$. hedracea and $66.66 \%$ in I. purpurea. In the same way, inter species locus contribution toward genetic diversity was $83.33 \%$. Interestingly, locus 2 (L-2) was monomorphic in the collected germplasms and may be shown as generic specific locus for Ipomoea species. SDS-PAGE profiling based on two-way cluster plotting successfully determined the two species into separate clusters and the diversity found between and within Ipomoea species may offer unique avenues for novel drug discovery.
\end{abstract}

Keywords: Ipomoea species; Ethno medicinal uses; Genetic diversity; SDS-PAGE; Cluster analysis

\section{Introduction}

The Ipomoea is an important genus belongs to family convolovulaceae; with many species of Ipomoea have wide therapeutic uses. Species are broadly dispersed throughout temperate and tropical regions and mostly found in tropical America and tropical Asia [1], used to treat blood disease, sterility in women, urinary infection, constipation and gynecological disorders [2]. The plant is also having laxative, psychedelic [3] anticarcinogenic, hepatoprotectivity, oxytocic and antioxidant properties [4] as well as in rheumatism and fungal infection [5].

Ipomoea species are used for its medicinal contents and psychoactive compounds mostly alkaloids. The genus Ipomoea comprises of food crops such as the tubers of sweet potatoes and the leaves of water spinachare are commercially important food stuffs. The most important species Ipomoea including I.hederacea and I. purpurea are growing in the hilly areas of Swat, Pakistan. The I. purpurea and I. hederacea are distinguishable by sepal and leaf characteristics. The I. purpurea sepals are ovate-lanceolate with an apex that is acute to abruptly acuminate while I. hederacea's sepals are lanceolate, longattenuate, and caudate. Leaves are ovate and deeply 3-lobed with acuminate tips and cordate bases. Stem twine with their apex in a dextral fashion [6-8].

Morphological characterization has important role in the exploration of genetic diversity in crop plants but effected by environmental changes [9]. On the other hand, genetic diversity evaluation through molecular methods such as biochemical assessment at protein level and DNA based techniques have a number of advantages over the classical morphology [10] but compared to biochemical assessment at protein level, molecular investigation of DNA level is highly robust but too expensive (Win et al., 2011). Among biochemical techniques, Sodium dodecyl sulphate polyacrylamide gel electrophoresis (SDS-PAGE) method is a simple, reliable, cheap and free of environmental fluxes [11]. SDS-PAGE is now broadly used biochemical practice to designate the genetic structure of crop germplasm (Hameed et al., 2009). Enormous attention has been focused on the use of SDS-PAGE over the last two decades for estimation of genetic diversity, reliable judgment and identification of plant varieties. Seed 
storage protein markers have been successfully used to resolve taxonomic relationships and characterize cultivated varieties in a number of crop plant species; An attempt for estimation of genetic relationships among the nine Ipomoea species using the molecular technique of sodium dodecyl sulphate polyacrylamide gel electrophoresis (SDS-PAGE) of seed proteins was carried out by Pragati et al. [12].

Pakistan is rich in naturally distributed species of Ipomea but there are no reports about the ethnomedicinal uses or genetic relationship of Ipomoea species based on total seed protein profiling available. In this article, we report on ethnomedicinal uses and SDS-PAGE analyses of 28 genotypes of Pakistani Ipomea species (I. hedracea and I. purpurea) growing in hilly areas of Swat. Both these species are locally adapted and are of widespread use as ornamental and medicinal purposes. The objective of the study to document the ethnomedicinal uses and level of genetic polymorphism and relationships among Pakistani Ipomoea species (I. hedracea and I. purpurea) growing in hilly areas of Swat using morphological and SDS-PAGE characterization.

\section{Material and Methods}

\section{Plant materials}

In the present study several exploratory trips were arranged to different agro-ecological zones of Swat in 2017 - 2018. During expedition, of different zones i.e. Swegalai, Kohay, Ziarat, Jawand, Gadi, Sharfabad, Rangila, Gharai, Khazana, Aboha, Barikot, Shingardar Manyar, Nawagai, Shahdeari, Sarsinai, Khawazakhela, Mangultan, Manglor, Chamtalai, Chaliyar, Baidara, Sherpalam, Kanju, Bandai, Derai and Hazara were selected for collection of samples for Ethno medicinal uses, morphological characterization and estimation of genetic diversity in seed storage protein profile. Specimens for each specie have been collected and processed using standard herbarium techniques [13]. The data was collected through semi structured interviews with inhabitants involved in the plant's management [13]. A total of 120 residents were interviewed for information on uses of plants to cure various diseases of human being, parts used, of medicine have been collected. Based on the information obtained from the informants in the study area, all the reported diseases have been classified into 9 groups. The use value (UV) demonstrates the relative importance of locally known plants [14]. It was calculated using the formula: $U V=\sum U i / N$, where Ui is the number of uses mentioned by each information for a given species and $\mathrm{N}$ is the total number of informants. The level of similarity among information delivered by various informants was calculated by the Informants' Consensus Factor or ICF [15] using the formula:

$I C F=N u r-N t /(N u r-1)$ Where, Nur = number of use reports from informants for a specific plant-use category; $\mathrm{Nt}=$ number of taxa or species that are used for that plant use category for all informants.

ICF Values range between 0 and 1 , where ' 1 ' indicates the highest level of informant agreement. The fidelity level (FL), the percentage of informants demanding the application of a certain plant species for the same major purpose, was counted for the most frequently reported diseases as: FL $(\%)=(\mathrm{Np} / \mathrm{N}) \times 100$ Where, $\mathrm{Np}=$ number of informants that claim a use of a plant species to treat a particular disease; $\mathrm{N}=$ number of informants that use the plants as a medicine to treat any given disease [13].

\section{Morphological characterization}

Qualitative and quantitative descriptors were taken. Qualitative traits were recorded on the general visualization (phenotypic observations). Nine qualitative traits i.e. Leaf Shape, Leaf Color, Leaf Pubescent, Flower color, Seed texture, Hilum color, Seed coat color, Seed shape, Spots on the seed coat while the quantitative traits were Petiole length, Leaf length, Leaf width, Seed length, Seed thickness, Seed width, Pod length, Seed per pod, Pod per plant, Flower length, Flower width, Seed weight, Branches per plant, Plant height, Biomass, Yield per plant. A total of 24 traits were recorded for morphological description.

\section{Protein Profiling}

To assess genetic diversity and genetic relationships, SDSPAGE was conducted (Lameli, 1970). For seed storage protein profile, single seed of each genotypes was crushed into a powder. $400 \mu \mathrm{l}$ of Protein Extraction Buffer PEB (0.5M Tris-HCL, 0.2\%SDS, $5 \mathrm{M}$ Urea, $1 \% \mathrm{~B}$-mercaptoethanol under 8-pH) was added to $0.01 \mathrm{~g}$ of seed powder. Then mixture in E-tube was Vortexed thoroughly to homogenize it. The Comassive Brilliant Blue (CBB) was added to the E-tube as tracking dye to see the movement of PEB-FP on the separation PAG. The homogenated samples were centrifuged at $13,000 \mathrm{rpm}$ for 10 minutes under room temperature. The electrophoretic process was carried out using $12 \%$ polyacrylamide gel (composition of resolution gel: 3.0M Tris- $\mathrm{HCl}$ pH9.0, 0.4\% SDS and staking gel $0.4 \mathrm{M}$ Tris- $\mathrm{HCl} \mathrm{pH} 7.0,0.4 \% \mathrm{SDS}$ ). The electrode buffer containing $0.025 \mathrm{M}$ Tris, $129 \mathrm{M}$ Glycine and $0.125 \%$ SDS was poured in the Electrophoresis tank. Similarly, 15 $\mu$ PEB-FP was loaded in each well of $12 \%$ PAG. The electrophoresis was run at $100 \mathrm{~V}$ until the blue line passed through the bottom of gel plates. The PAG were than stained and destained for data scoring of seed storage protein profile.

\section{Data analysis}

Morphological data was analyzed through cluster plotting using software's SPSS and PC-ORD.

\section{Results}

In this research work 2 plant species of Ipomoea (I. hederacea and I. purpurea) belonging to Convolovulaceae family in Swat Valley, have been in listed for curing of 12 categories of ailments. For each species botanical name, family, local name, ailments to be treated, and part(s) used were noted (Table1).

\section{Traditional uses of Ipomoea L.}

Residents' perspectives about this plant evaluated in this category of results were very interesting. The responses of the 
people about the medicinal uses of Ipomoea L. are summarized (Table 1). In the common domain, the plant was used for the treatment of Blood purifier, Infertility, Rheumatism, Fungal infection, Liver protection, Acne, Urinary infection, Diarrhea, Constipation (Table 1). About $100 \%$ of people used it as Blood purifier, $91.666 \%$ people used it for Infertility, $72.5 \%$ for Rheumatism, 75\% for reducing Fungal infection , 75\% used it for Liver protection , 62.5\% it for Acne, 58.333 for Urinary infection, $41.666 \%$ for Diarrhea $25 \%$ used it for Constipation (Table 2).

Table 1: Documentation of medicinal plants with scientific name, local name, parts used, and ailments.

\begin{tabular}{|c|c|c|c|c|c|c|c|}
\hline S.No & $\begin{array}{l}\text { Botanical } \\
\text { Name }\end{array}$ & Family & Voucher No & Local Name & Habit & Part Used & Ethnobotanical Uses \\
\hline 1 & $\begin{array}{l}\text { I. hederacea (L.) } \\
\text { Jacq }\end{array}$ & Convolovulaceae & HUP-7573 & Peek gulay & Herb & $\begin{array}{l}\text { Bark, leaves, } \\
\text { Seeds }\end{array}$ & $\begin{array}{c}\text { Infertility, Rheumatism, Fungal infection, } \\
\text { Liver protection, Infertility, Urinary } \\
\text { infection, Diarrhea, Constipation, Blood } \\
\text { purifier }\end{array}$ \\
\hline 2 & I. purpurea L & Convolovulaceae & HUP-7574 & Pick gulai & Herb & Leaves, Seeds & $\begin{array}{l}\text { Infertility, Rheumatism, Fungal infection, } \\
\text { Liver protection, Infertility, Urinary } \\
\text { infection, Diarrhea, Constipation }\end{array}$ \\
\hline
\end{tabular}

Table 2: uses value of Ipomoea L. in District Swat.

\begin{tabular}{|c|c|c|c|c|}
\hline Diseases & $\boldsymbol{\Sigma} \mathbf{U i}$ & $\mathbf{N}$ & Use Value (UV) & \%UV \\
\hline Blood purifier & 120 & 120 & 1 & 100 \\
\hline Infertility & 110 & 120 & 0.916 & 91.666 \\
\hline Rheumatism & 87 & 120 & 0.725 & 72.5 \\
\hline Fungal infection & 90 & 120 & 0.75 & 75 \\
\hline Liver protection & 90 & 120 & 0.75 & 75 \\
\hline Acne & 75 & 120 & 0.625 & 62.5 \\
\hline Urinary infection & 70 & 120 & 0.583 & 58.333 \\
\hline Diarrhea & 50 & 120 & 0.416 & 41.666 \\
\hline Constipation & 30 & 120 & 0.25 & 25 \\
\hline
\end{tabular}

\section{Conservation signs of Ipomoea L.}

Responses to the status about the survival of the species suggest that over $74.166 \%$ of the respondents agree that the plant has survived due to ornamental value, $65 \%$ people relate it to medicinal value, $60 \%$ relate it to presence on fertile soil, $72.5 \%$ of respondents believed its survival was due to its good water absorption. Similarly, $55.833 \%$ of the informants suggested that it has survived because of its strong secondary growth system (Table 3).

\section{Declination signs of Ipomoea L.}

In the present study, reasons for the serious decline of Ipomoea in the study area were also investigated. The most important reason for its decline recorded was overuse of the seed and leaves. Other reasons included overgrazing or use as forage, lack of protection, water logging and salinity, less resistant to drought condition etc. (Table 3). Major source of its decline $(73.333 \%)$ was regarded due to its overuse of the seed and leaves, $70.833 \%$ of respondents regarded its decline to the non-existence of any conservation measures, 65\% mentioned water logging and salinity as important reason of its decline while, 55.83\% of respondents regarded the lack of drought resistance as the major reason of its decline (Table 3 ).

Table 3: Different reasons for survival and decline of Ipomoea $L$. in District Swat

\begin{tabular}{|c|c|c|c|c|}
\hline Reasons for Survival & SUi & N & Use Value (UV) & \%UV \\
\hline Protection due to ornamental vale & 89 & 120 & 0.741 & 0.65 \\
\hline Protection due to medicinal vale & 78 & 120 & 0.725 & 65 \\
\hline Good water absorption & 72 & 120 & 0.6 & 72.5 \\
\hline Presence on fertile soil & 71 & 120 & 0.558 & 55.833 \\
\hline Strong secondary growth system & 67 & 120 & & 73.333 \\
\hline $\begin{array}{c}\text { Different Reasons for Decline of } \\
\text { Ipomoea } \boldsymbol{L} \text {. in District Swat }\end{array}$ & & & 0.741 & 70.833 \\
\hline Overuse of the seed and leaves & 89 & 120 & 0.708 & 65 \\
\hline Overgrazing use as forage & 85 & 120 & 0.65 & 58.3 \\
\hline Lack of protection & 78 & 120 & 0.583 & 55.833 \\
\hline Water logging and salinity & 70 & 120 & 0.558 & \\
\hline less resistant to drought condition & 67 & 120 & & \\
\hline
\end{tabular}

Use of plant parts as medicine among the informants demonstrated variations. Leaves and seeds are mostly used part for majority, followed by bark (Table 1). Similar trend of harvesting leaves for medicinal use has also been reported from Lawachara National Park [16]. In the present study area threat to the species is marginal as leaves are the leading plant part used for medicinal 
purposes. It was perceived that the collection of part of plant as medicinal part from the wild were not manageable. According to inhabitants, the collectors are involved in this illegal trade of Ipomoea species as well as other important medicinal plants of this area.

ICF values were calculated to know the settlement among the informants of Swat valley for consumption of plants to treat certain ailment categories. The ICF values are given in the Table 2 and varied from 0.991 to 0.965 with an average ICF value of 0.978 . Blood purifier has the highest ICF value 0.991 with 120 use-reports for 1 plant species. The specie accountable for this high consensus was I. hederacea. With 120 of the 120 defined events, linked by Infertility (ICF $=0.99 ; 110$ use-reports, 2 species), Rheumatism (ICF $=0.988 ; 87$ use-reports, 2 species), Fungal infection (ICF= 0.988, 90 use reports, 2 species) and so on. Medicinal plants thought to be effective in treating specific illness have high ICF values. The high ICF value for Blood purifier perhaps disclosed that this ailment is common in the study area High ICF values also designate that the specie conventionally used to treat these ailments are worth searching for bioactive compounds. The least agreement $(\mathrm{ICF}=0.985$ and $\mathrm{ICF}=0.965)$ between the informants was observed for Urinary infection, Diarrhea and Constipation respectively. The low ICF value as noted in our study could be due to a lack of communication among people in different areas (Table 4 \& Figure 1)

Table 4: Categories of disorders and informant consensus factor (ICF) for each grouping.

\begin{tabular}{|c|c|c|c|c|}
\hline S.No & Disease Category & Use Reports & Taxa Used & ${ }^{*}$ ICF \\
\hline 1 & Blood purifier & 120 & 1 & 0.991 \\
\hline 2 & Infertility & 110 & 2 & 0.99 \\
\hline 3 & Rheumatism & 87 & 2 & 0.988 \\
\hline 4 & Fungal infection & 90 & 2 & 0.988 \\
\hline 5 & Liver protection & 90 & 2 & 0.988 \\
\hline 6 & Acne & 75 & 2 & 0.986 \\
\hline 7 & Urinary infection & 70 & 2 & 0.985 \\
\hline 8 & Diarrhea & 50 & 2 & 0.979 \\
\hline 9 & Constipation & 30 & 2 & 0.965 \\
\hline
\end{tabular}

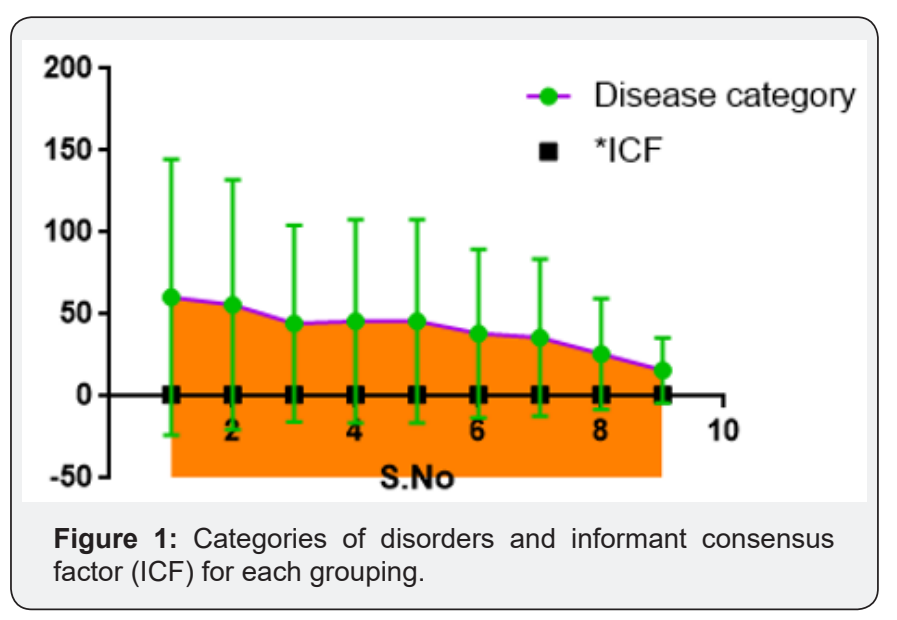

To find conventionally medicinal significance of the Ipomoea species in the area, Fidelity Level (FL) of plants has been predicted based on use reports, which have been cited by 50 or more informants for being used against a given illness. The FL values are shown in Table 5. The investigation displayed that the highest FL value found in $I$. hederacea followed by $I$. purpurea. The least FL value was found in the case of I. purpurea. FIC and FL studies presented that the most commonly used species in the study area is $I$. hederacea $(\mathrm{ICF}=0.991$ ) with 120 use-reports and FL value (100\%). When choosing the most ideal plant species for each ailment category, we took the high-Fidelity Level (\%) in each category of ailment.

Table 5: Utmost frequently used plants for various illness groups based on highest FL $(\%)$ in each disease category (Total informants $=120$ ).

\begin{tabular}{|c|c|c|c|}
\hline $\begin{array}{c}\text { Scientific } \\
\text { Name }\end{array}$ & $\begin{array}{c}\text { Disease } \\
\text { Category }\end{array}$ & Use Report & $\begin{array}{c}\text { Fidelity Level } \\
\text { (\%) }\end{array}$ \\
\hline $\begin{array}{c}\text { I. hederacea } \text { (L.) } \\
\text { Jacq. }\end{array}$ & Blood purifier & 120 & 100 \\
\hline I. purpurea L. & Common Pain & 110 & 91.66 \\
\hline
\end{tabular}

\section{Intra and inter specific genetic variation based on agro- morphological and SDS-PAGE}

To determine the intra and inter specific variation among the Ipomea Species, morphological and biochemical characterizations (SDS-PAGE) were carried out. The germplasm for this study were collected from different areas of Swat.

SDS-PAGE is one of the most extensively used techniques to separate total seed protein sub-units and to understand phylogenetic relationship of plant species. The protein in SDSPAGE is separated according to the change in their molecular weight. In this study 28 genotypes of two species i.e. I. hedracea and I. purpurea, 14 of each were carried out. Each sample was run on the gel in order to investigate the intra and inter specific genetic diversity among them.

\section{Morphological characterization}

For morphological data analysis both the qualitative and quantitative traits were taken. Quantitative traits which were measured with the help of vernier calipers are: petiole length (PL), leaf length (LL), leaf width (LW), seed length (SL), seed width (SW), seed thickness (ST), and seed weight (SWt), pod length (PodL), No. of seed per pod (SP), No. of pod per plant (PP), inflorescence length (IL), inflorescence width (IW), 100 seed weight, No. of branches per plant, plant height $(\mathrm{Ph})$, Biomass. Characters mean was found out after measuring of 3 different samples (small, medium, large) of each quantitative character.

The observed qualitative characters are leaf type (LTY), leaf color (LC), seed texture (St), Hilum color (Hc), seed coat color (SC), seed shape (SS), leaf pubescent, leaf stipule presence, flower color. The data of both quantitative and qualitative characters of 28 genotypes (total 24 characters) was recorded and the binary matrix data was subjected to computer software the PCORD and the cluster analysis was presented as in Figure 2. 


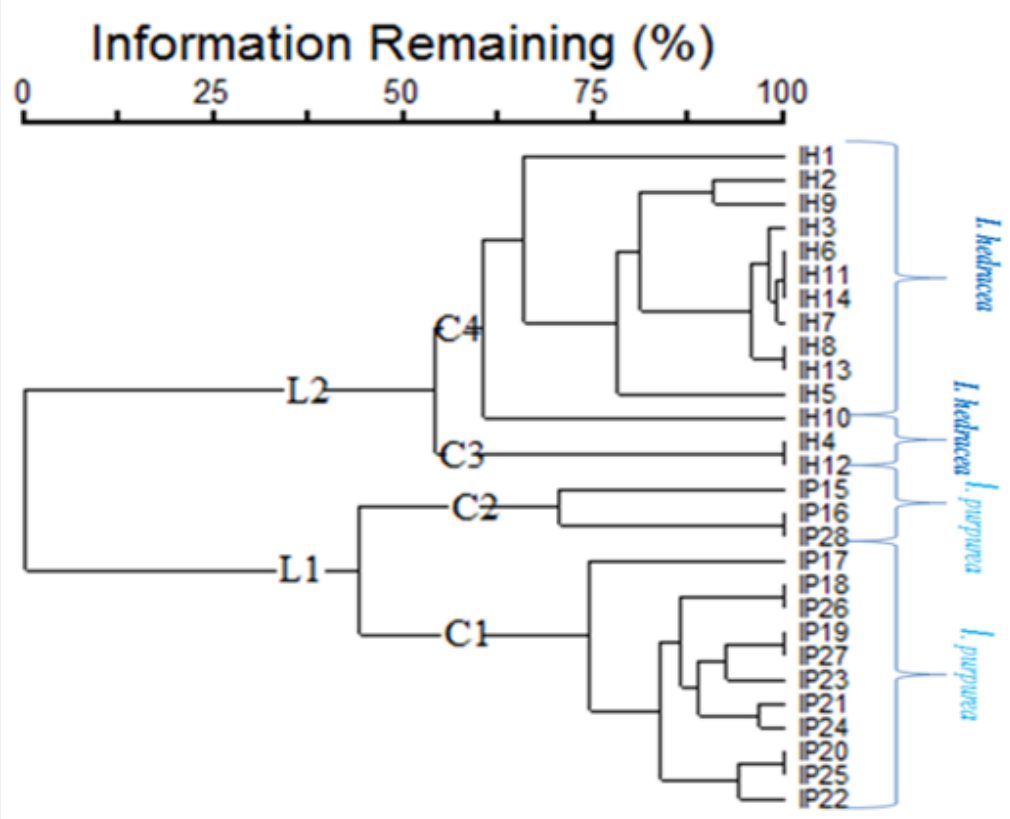

Figure 2: Inter -species phylogenetic relationship identified through morphological traits analysis in 28 different genotypes of Ipomoea species collected from Swat, Khyber Pakhtunkhwa, Pakistan. IP indicate genotypes of $I$. purpurea, and IH represents $I$. hedracea.

By using the Pearson correlation coefficient, the result for the association coefficient among the various traits for the two species of Ipomoea (I. hedracea and V. I. purpurea) was performed (Table 6). In correlation study the petiole length in the I. hedracea, is negatively correlated with leaf length in the while positively correlated with leaf length in I. purpurea. Leaf width is negatively correlated with the leaf length in I. hedracea while positively correlated in the I. purpurea. The flower length in I. hedracea and I. purpurea is negatively correlated with the leaf length and leaf width. Seed length seed width, seed thickness, No. of the Pods/ Plant, No. of seed/ Plant and 100 seed weight are negatively correlated with petiole length, leaf length, leaf width, inflorescence length, flower length and pod length in both the species.

Table 6: Correlation coefficient among sixteen quantitative traits of $I$. hedracea and $I$. purpurea.

\begin{tabular}{|c|c|c|c|c|c|c|c|c|c|c|c|c|c|c|c|c|}
\hline Traits & PL & LL & LW & SL & ST & SW & PodL & $\mathrm{S} / \mathrm{P}$ & $\mathrm{P} / \mathrm{P}$ & FL & FW & SWT & $\mathrm{B} / \mathrm{P}$ & $\mathrm{PH}$ & $\begin{array}{c}\text { BM } \\
\text { (gram) }\end{array}$ & $\mathrm{Y} / \mathrm{P}(\mathrm{gram})$ \\
\hline PL & 1.00 & 0 & 0.4 & -0.1 & 0.1 & 0.4 & 0.5 & $.851^{* *}$ & -0.5 & $.896^{* *}$ & 0.1 & 0.5 & -0.5 & $.895^{* *}$ & $0.683^{* *}$ & 0.5 \\
\hline LL & $-.588^{*}$ & 1.00 & $-.685^{* *}$ & 0 & -0.4 & -0.5 & -0.3 & -0.2 & 0.3 & $-.627^{*}$ & $.560^{*}$ & $.574^{*}$ & 0.2 & $-.867^{* *}$ & $0.709^{* *}$ & 0.5 \\
\hline LW & $-.566^{*}$ & 0.4 & 1.00 & -0.4 & 0.2 & -0.5 & -0.3 & -0.1 & 0.1 & $.723^{* *}$ & -0.4 & $.712^{* *}$ & 0.4 & $.767^{*}$ & -0.5 & $0.802^{* *}$ \\
\hline SL & -0.3 & $.542^{*}$ & 0.2 & 1.00 & -0.3 & 0.4 & -0.1 & 0 & 0.2 & 0.3 & $.819 * *$ & -0.5 & $.944^{* *}$ & 0.4 & $.553^{*}$ & $-0.660^{*}$ \\
\hline ST & 0.3 & -0.4 & -0.4 & $-.589^{*}$ & 1.00 & $.569^{*}$ & 0.1 & 0.3 & $.542^{*}$ & 0.3 & 0.3 & -0.3 & $.791^{* *}$ & $-.627^{*}$ & -0.4 & -0.1 \\
\hline SW & 0.4 & -0.1 & -0.1 & $-.671^{* *}$ & 0.3 & 1.00 & -0.3 & 0.4 & -0.2 & 0.1 & 0.4 & 0.4 & $.677^{* *}$ & 0.1 & 0.4 & 0.1 \\
\hline PodL & $-.585^{*}$ & $.717^{* *}$ & 0.4 & $.533^{*}$ & -0.1 & -0.4 & 1.00 & -0.3 & -0.2 & $-.564^{*}$ & -0.3 & -0.5 & -0.5 & 0.1 & 0 & 0.2 \\
\hline$S / P$ & -0.1 & -0.1 & 0.2 & -0.3 & 0 & 0 & 0 & 1.00 & -0.2 & 0.5 & 0.1 & 0.1 & 0.3 & 0.4 & $0.790^{* *}$ & $-0.560^{*}$ \\
\hline $\mathrm{P} / \mathrm{P}$ & 0.4 & -0.4 & -0.3 & -0.5 & 0.4 & 0.5 & -0.3 & 0.4 & 1.00 & 0.3 & 0.2 & 0.3 & $.641^{*}$ & 0.3 & 0.1 & -0.2 \\
\hline FL & 0 & 0.5 & $.577^{*}$ & 0 & -0.2 & 0.4 & 0.2 & -0.2 & -0.2 & 1.00 & 0.3 & 0.5 & 0 & 0.3 & 0.5 & $0.590^{*}$ \\
\hline FW & 0.5 & -0.3 & $-.740^{* *}$ & -0.5 & $.779^{* *}$ & 0.3 & -0.1 & -0.1 & 0.3 & -0.3 & 1.00 & 0.2 & $.753^{* *}$ & $.598^{*}$ & $.690^{* *}$ & $0.930^{* *}$ \\
\hline SWT & -0.2 & $.536^{*}$ & 0.3 & 0.1 & 0.1 & 0.2 & 0.1 & -0.1 & -0.5 & $.578^{*}$ & -0.1 & 1.00 & 0.3 & $.790^{* *}$ & $.696^{* *}$ & $0.854^{* *}$ \\
\hline $\mathrm{B} / \mathrm{P}$ & 0.3 & 0.1 & 0.4 & 0.1 & -0.3 & 0.3 & -0.1 & -0.5 & -0.1 & $.721^{* *}$ & -0.3 & 0.1 & 1.00 & 0.5 & $0.722^{* *}$ & $0.738^{* *}$ \\
\hline $\mathrm{PH}$ & $-.618^{*}$ & 0.4 & 0.4 & -0.2 & -0.1 & 0.1 & 0.4 & $.683^{* *}$ & 0.2 & 0 & -0.2 & -0.1 & -0.4 & 1.00 & 0.2 & $0.711^{* *}$ \\
\hline BM (gram) & 0.4 & 0.1 & -0.2 & 0.3 & 0.1 & 0.1 & -0.1 & -0.5 & -0.2 & 0.3 & -0.1 & 0.5 & 0.3 & $-.624^{*}$ & 1.00 & 0.1 \\
\hline $\mathrm{Y} / \mathrm{P}$ (gram) & 0.2 & 0.1 & $-.560^{*}$ & -0.2 & -0.1 & 0.2 & 0 & 0.1 & 0.2 & -0.2 & 0.4 & -0.4 & -0.2 & 0.3 & -0.4 & 1.00 \\
\hline \multicolumn{17}{|c|}{ *. Correlation is significant at the 0.05 level (2-tailed). } \\
\hline \multicolumn{17}{|c|}{ **. Correlation is significant at the 0.01 level (2-tailed). } \\
\hline
\end{tabular}


The double data matrix of 28 genotypes based on morphology was analyzed for the construction of phylogenetic tree to represents the similarity of various species or genera and the two species of the Ipomoea were investigated for similarities and the phylogenetictree was constructed (Figure 2). The phylogenetic tree divided the two species in two lineages L1 and L2 at a linkage distance 37.5 (Figure 1). L1 consisted of two clusters; (C1) and (C2). The $\mathrm{C} 1$ and $\mathrm{C} 2$ comprised of all genotypes of I.heracea. While the L2 was further divided into two clusters; C3, C4 composed of all genotypes of $I$. hedracea.

The similarity indexes were performed for all the genotype of 2 species that was 33.33 for I. hedracea and I. purpurea (Table 7).

Table 7: Intra and interspecific genetic diversity in 24 morphological characters studied in I. hederacea and I. purpurea.

\begin{tabular}{|c|c|c|c|}
\hline \multirow{2}{*}{ Traits } & \multirow{2}{*}{ I. hedracea } & \multirow{2}{*}{ I. purpurea } & Trait Similarity Index \\
\hline & & & I.h\& I.p \\
\hline PL & 8.2666 & 11.07 & NA \\
\hline LL & 9.5 & 6 & NA \\
\hline LW & 6.5 & 4.444 & NA \\
\hline IL & *4.0866 & *3.952 & $* 4.0193$ \\
\hline IW & 4.8 & 3.065 & NA \\
\hline SL & *3.9333 & $* 2.663$ & *3.298 \\
\hline SW & 8.333 & 4.8 & NA \\
\hline ST & $* 3.9$ & *3.866 & $* 3.883$ \\
\hline PodL & 24.5 & 16.4 & NA \\
\hline $\mathrm{S} / \mathrm{P}$ & 5.8966 & 3.666 & NA \\
\hline $\mathrm{P} / \mathrm{P}$ & 4.5666 & 3.06666 & NA \\
\hline SWt & 69.9 & 51.9 & NA \\
\hline $\mathrm{B} / \mathrm{P}$ & 17.233 & 9.233 & NA \\
\hline $\mathrm{PH}$ & 113.2 & 77.5333 & NA \\
\hline BM & 211.5 & 115.2 & NA \\
\hline $\mathrm{Y} / \mathrm{P}$ & 88.1 & 58 & NA \\
\hline LS & Ovate & Cordate & NA \\
\hline LC & *Green & *Green & *Green \\
\hline LP & *Present & *Present & *Present \\
\hline $\mathrm{FC}$ & Purple White & White blue & NA \\
\hline St & rough/smooth & granular & NA \\
\hline $\mathrm{HC}$ & *Dull brown & *Dull brown & *Dull brown \\
\hline $\mathrm{SCc}$ & Dull grey & Dull brown/black & NA \\
\hline SS & *Wedge shaped & *Wedge shaped & *Wedge shaped \\
\hline SpT & *Present & *Present & *Present \\
\hline \multicolumn{3}{|c|}{ Total TSI $=(($ homologous trait/total traits $) * 100)$} & 33.33 \\
\hline
\end{tabular}

\section{SDS- PAGE analysis}

Six reproducible bands were observed in the both the species, (Figure 3). The phylogenetic relationship among the 2 species through phylogenetic tree has been shown in the (Figure 4). The phylogenetic tree was splitted into eight groups. Groups I comprised of only one genotype of I. purpurea collected from Swegalai (IP16). Group I was 25\% genetically similar with II which was composed of 5 genotypes of I. purpurea collected from Kohay (IP24), Ziarat (IP25), Jawand (IP26), Gadi (IP27) and Sharfabad (IP28). Group III has 37.7 similarity with the genotypes of Group II while $50 \%$ similar with the genotypes of Group IV. These genotypes were collected from Rangila (IP17), Gharai (IP18), and
Khazana (IP19). Group V has $81.25 \%$ similarity with the genotypes of Group VI. The genotype of Group IV was collected from Aboha (IP15. Group V comprised of 4 genotypes collected from Barikot (IP20), Shingardar (IP21), Manyar (IP22), Nawagai (IP23). Group VI and Group II only one genotypes of I. hedracea collected from Shahdeari (IH14) and Sarsinai (IH9) respectively. I. hedracea has separatd from $I$. purpurea at a linkage distance $81.25 \%$. $I$. hedrarcea and I. purpurea has $81.25 \%$ genetic similarity. The genotypes of Group VII and Group VIII 93.75\% similar which were collected from Khawazakhela (IH4), Mangultan (IH6), Manglor (IH10), Chamtalai (IH1), Chaliyar (IH2), Baidara (IH3), Sherpalam (IH5), Kanju (IH7), Bandai (IH8), Derai (IH11) and Hazara (IH). 


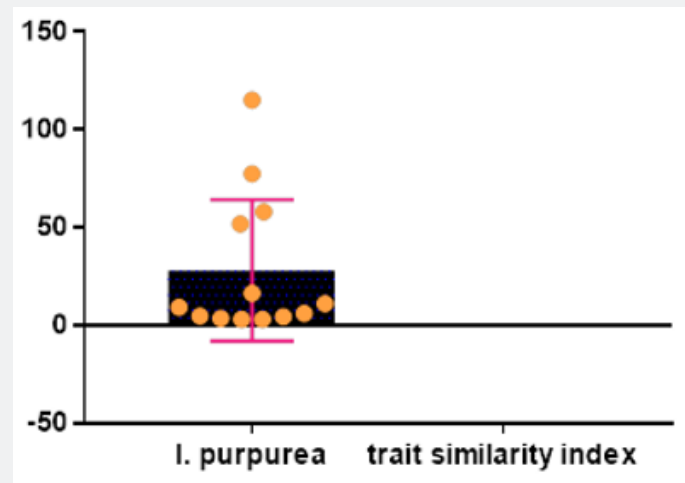

I. purpurea

- trait similarity index

\section{I. hedracea}

Figure 3: Intra and interspecific genetic diversity in 24 morphological characters studied in $I$. hederacea and $I$. purpurea.

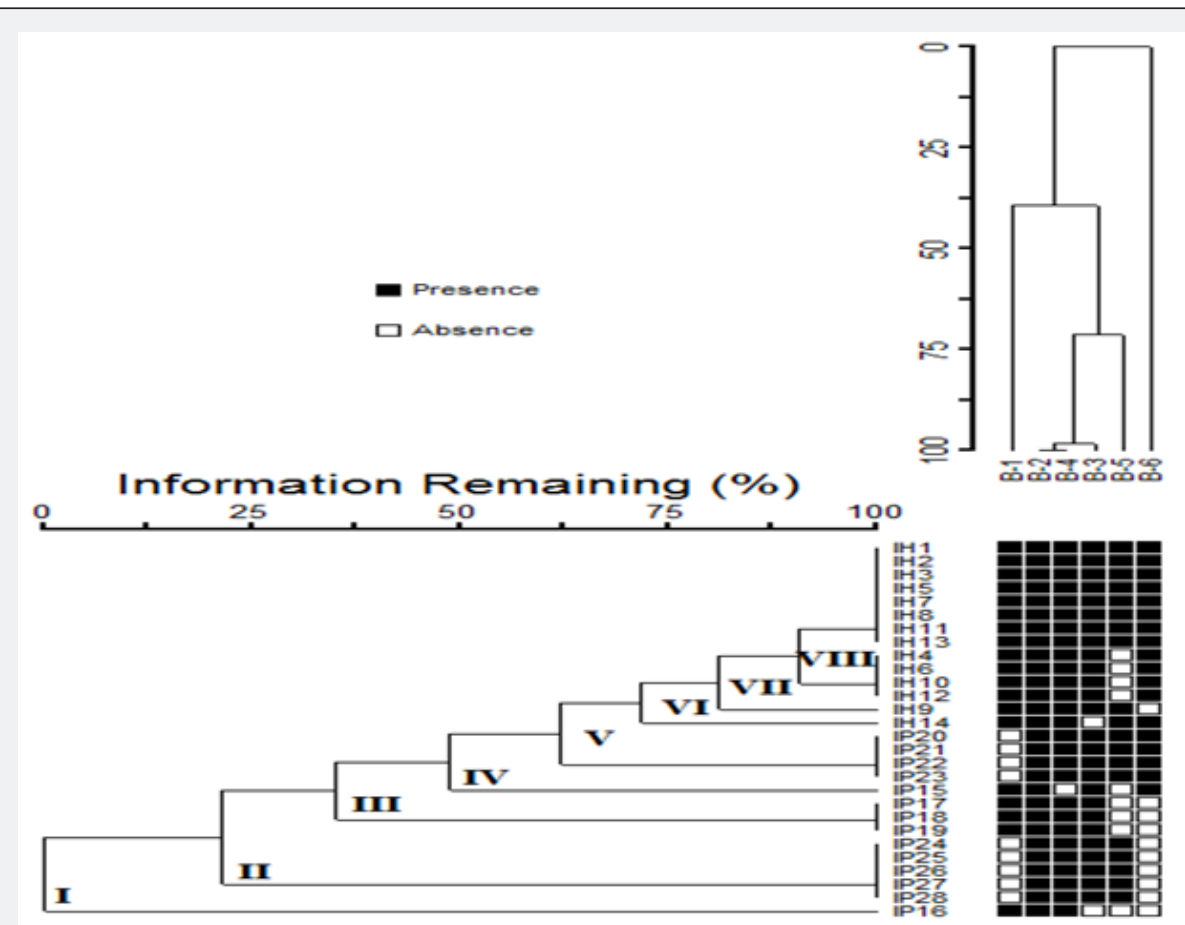

Figure 4: Inter -species phylogenetic relationship identified through SDS_PAGE analysis in 28 different genotypes of Ipomoea species collected from Swat, Khyber Pakhtunkhwa, Pakistan. IP indicate genotypes of I. purpurea, and IH represents I. hedracea.

\section{Locus variation}

Table 8: Inter-locus variations among I. hederacea and I. purpurea.

\begin{tabular}{|c|c|c|c|c|c|}
\hline Locus & Present (\%) & Absent (\%) & Variation (\%) & Status & GD \\
\hline L-1 & $19(67.85 \%)$ & $9(32.14 \%)$ & 32.14 & poly & mono \\
\hline L-2* generic specific locus & $28(100)$ & 0 & Nil & poly & 0.678 \\
\hline L-3 & $26(92.857)$ & $2(7.142)$ & 7.142 & poly & 0.964 \\
\hline L-4 & $27(96.428)$ & $1(3.571)$ & 3.571 & poly & 0.678 \\
\hline L-5 & $19(67.85 \%)$ & $9(32.142)$ & 32.14 & poly & 0.9 \\
\hline L-6 & $18(90)$ & $10(35.714)$ & 35.71 & \\
\hline
\end{tabular}

Table 8 and Figure 5 show interspecific variation among 28 loci (L1-L6) were noted out these L2 was monomorphic and genotypes of the Ipomea species. Among all the genotypes, six were marked as generic specific which is used to discriminate 
the Ipomea species. Moreover, the loci L-1, L-4 and L-6, marked as polymorphic with $32.14,7.142,3.571,32.14$ and35.71 percent genetic diversity, respectively. The inter species comparative locus

contribution toward genetic disagreement (CLCTGD) was $83.33 \%$ in the two species of 28 Ipomoea genotypes (Table 8 \& Figure 5).

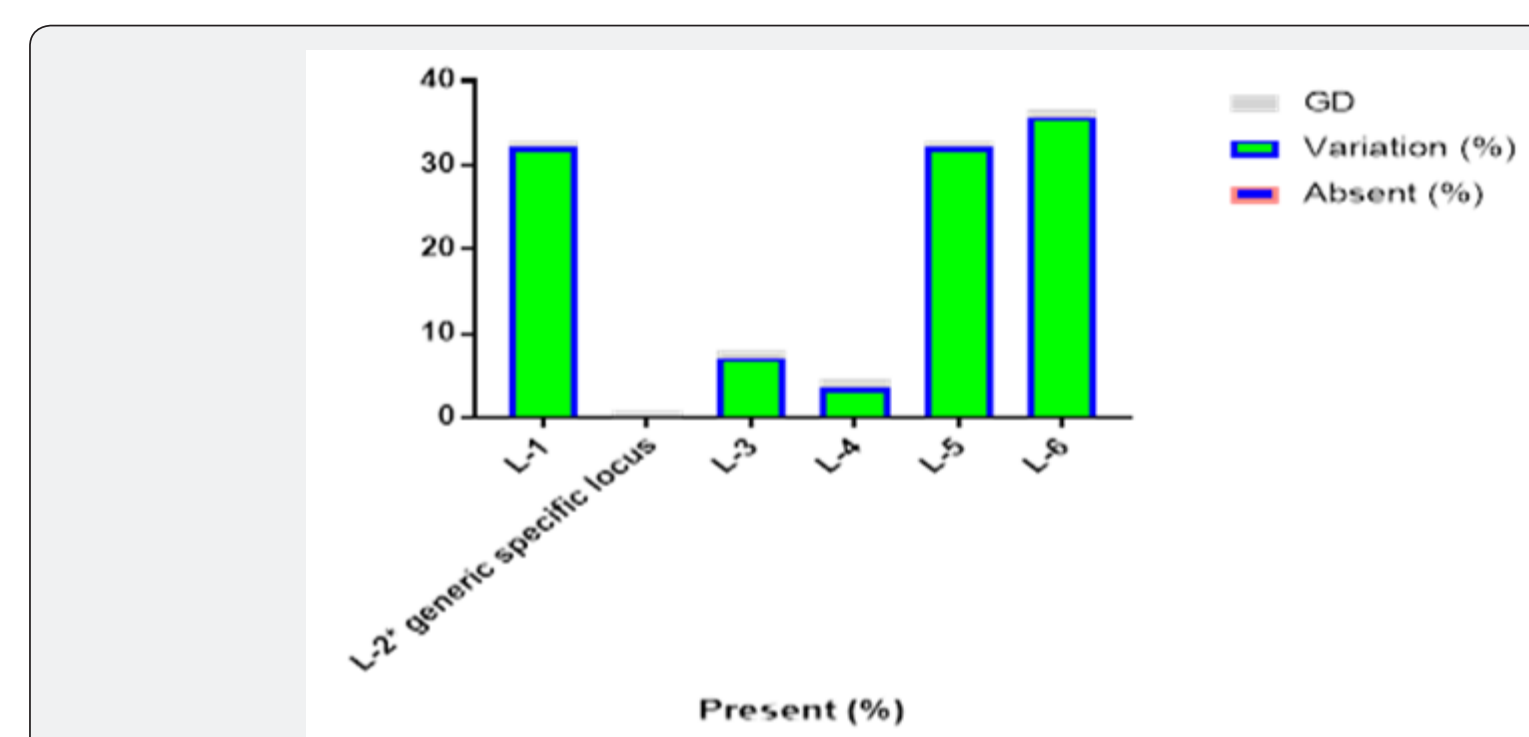

Figure 5: interspecific locus variations among I. hederacea and I. purpurea.

Intraspecific locus variation among 14 genotypes of $I$. hedracea is represented in Table 9 Notably, L-1, L-2. L-3, L-4 was monomorphic in I. hedracea. While L-5 and L- 6 was polymorphic. L-5 and L-6 shows 28.571 and 92.85, 17.24, 100 percent variation and the locus contribution toward genetic disagreement (LCTGD) of $I$. hedracea was $33.33 \%$ table 9 .
The table 9 represents the intraspecific variation among the 14 genotypes of I. purpurea, exhibited high intra-specific locus variation. Among six loci, out of which L-2 was monomorphic, while L-1, L-3, L-4, L-5 and L-6 were polymorphic showed 64.28, 7.14, 37.7 and 164.28 percent variation. The locus contribution toward genetic disagreement (LCTGD) of I. purpurea was $22.22 \%$.

Table 9: Intra-locus variations among genotypes of $I$. hedracea and $I$. purpurea.

\begin{tabular}{|c|c|c|c|c|c|}
\hline Locus & Present (\%) & Absent (\%) & Variation (\%) & Status & GD \\
\hline $\mathrm{L}-1$ & $14(100 \%)$ & 0 & $\mathrm{Nil}$ & mono & 1 \\
\hline L-2* generic specific locus & $14(100)$ & 0 & Nil & mono & 1 \\
\hline $\mathrm{L}-3$ & $14(100 \%)$ & 0 & Nil & mono & 1 \\
\hline$L-4$ & $14(100 \%)$ & 0 & Nil & mono & 1 \\
\hline $\mathrm{L}-5$ & $10(71.42 \%)$ & $4(28.571)$ & 28.57 & poly & 0.7142 \\
\hline L-6 & $1(7.14)$ & $13(92.85)$ & 35.71 & poly & 0.714 \\
\hline \multicolumn{6}{|c|}{ Intra-Locus Variations among Genotypes of I. purpurea } \\
\hline $\mathrm{L}-1$ & $5(35.71 \%)$ & $9(64.28 \%$ & 64.28 & poly & 0.357 \\
\hline L-2* generic specific locus & $14(100)$ & 0 & Nil & mono & 1 \\
\hline $\mathrm{L}-3$ & $13(92.85 \%)$ & $1(7.142)$ & 7.14 & poly & 0.928 \\
\hline$L-4$ & $14(100 \%)$ & 0 & Nil & mono & 1 \\
\hline$L-5$ & $9(64.28 \%)$ & $5(37.71 \%)$ & 37.71 & poly & 0.6428 \\
\hline L-6 & $5(37.71 \%)$ & $9(64.28 \%)$ & 64.28 & poly & 0.377 \\
\hline \multicolumn{6}{|c|}{ GD in $\mathrm{IP}=66.66$ and GD in $\mathrm{IH}=33.33$ (Poly loci/total loci*100) } \\
\hline
\end{tabular}

\section{Discussion}

A vast majority of the public living in this area depends directly on medicinal plant to cure an extensive range of diseases. However, the disappearance of these plant species is steadily reported chiefly due to fluctuations in the environment, land degradation and unsustainable use of these plants; moreover, the expansion of invasive species has donated a lot to their disappearance [17]. According to the local inhabitants the reason for its decline recorded was overuse of the seed and leaves. Other reasons included overgrazing or use as forage, lack of protection, water 
logging and salinity as well as less resistant to drought condition [18]. The present work has been subsequently initiated with an objective to file the knowledge and practices on the Ipomoea medicinal uses by the local inhabitants and its genetic diversity. The present study is supposed to add up the communities' knowledge in the country's database of traditional knowledge and will provide a baseline data for future pharmacological and phytochemical studies. Genetic diversity suits more vital in viewpoint of climatic change and associated unexpected events as it may serve as the source of novel traits considering tolerance to different biotic and abiotic stresses [9].

Though, the indigenous knowledge that has been recognized was previously eroded, if not in all, formerly in most of the parts studied [17]. Contributions concerning conservation of traditional knowledge remain scarce [19]. Therefore, the study focused on identifying local factors that promote the knowledge on introduced and native medicinal plant species, and to describe medicinal uses of plant species.

The present work is one of the first efforts to count the ethnomedicinal information and interspecies genetic diversity in Ipomoea species (I. hederacea and I. purpurea) from Swat which offer better choice for the selection of broadly used medicinal plants looking for bioactive compounds to cure illnesses. The effectiveness and safety of the reported ethnomedicinal plants need to be assessed by phytochemical and pharmacological studies. Plants with high informant consensus factor use report and fidelity level should be given priority to carry out bioassay and toxicity studies. From this study we suggest $I$. hederacea for further ethno pharmacological studies, since this species has the high ICF and FL values. The results showed that this species may be castoff for the improvement of new, cheap, effective, and ecofriendly herbal formulations for healthcare organization. Further use of these herbal formulations for healthcare management will require safety and effectiveness testing. According to inhabitants and our observations in the field, I. hederacea is now a very infrequent plant in the area. Illegal and unsustainable collection of leaves from this plant by the local crude drug traders is one of the major causes of depletion of this species from nature. There is crucial want to formulate suitable conservation strategies for naturally growing ethno medicinal plants to overcome their depletion from natural resources and to make these practices more ecofriendly [16].

The study of genetic diversity and phylogenetic relationship in medicinal plant species is helpful in their conservation. Molecular markers are the most effective markers for genetic polymorphism studies in many species [20]. However, the use of biochemical markers based on total seed protein and enzyme by SDS-PAGE method has been a reliable, yet inexpensive method. Genetic markers for identification and genetic analyses of several plant species, as they reveal differences between storage proteins or enzymes encoded by different alleles at a single (allozymes) or more gene loci (isozymes) [21].
However, up to date, the present study for the estimation of inter species phylogeny among the selected species (I. hedracea and I. purpurea) through morphological and SDS-PAGE is the first documented report from this area. As the SDS-PAGE has been used as a practical and reliable method for species Phylogenetic relationship and identification [22], therefore, the present study was conducted that displayed positive results with low inraspecific and high inter-specific divergence that could enable us to distinguish two species through SDS-PAGE.

The two plant species under the genus Ipomea study revealed that no two plants have similar protein banding patterns which demonstrates the presence of genetic diversity between these species. The presence of common bands/locus (L-2) among these two Ipomea species suggests their close genetic similarity and common ancestry. These loci coded for by a gene that has become fixed in different species under genus Ipomea over evolutionary time that is an agreement with work of [23] that the presence of common bands in Lycopersicum and Trichosanthes species describes their common evolutionary origin. Also, [24] accredited the appearance of a common locus/band in all individual in a population to the fact that the gene coding for the enzyme or protein does not differ.

Due to High inter-species locus contribution toward genetic disagreement SDS-PAGE could be a reliable technique for identification of these two species, while intra-specie locus contribution toward genetic discrepancy was high in genotypes of I. purpurea (66.66\%) as compare to I. hedracea (33.33\%) [25].

In our present work, phylogenetic tree based on seed storage protein analyses of selected species of Ipomea presented that the two species of Ipomea had close similarity to one another. The result showed that the $I$. purpurea was clustered adjacent to $I$. hedracea at linkage distance $81.25 \%$ genetic similarity and has revealed genetic relatedness $81.25 \%$ to I. hedracea. The results obtained afterSDS-PAGE electrophoresis disclosed that the method provided a powerful tool for reliable germplasm discrimination based on genetic differences in seed storage protein compared to selected germplasm of Ipomoea. Thus, the present study explores the existing polymorphism of total proteins through SDS PAGE to facilitate characterization of selected germplasm of Ipomoea [26].

\section{Conclusion}

The current work provides evidence that medicinal plants have an important role in the healthcare system of Swat area. They continue to depend on medicinal plants for the treatment of healthcare problems. The current paper documented a significant ethnobotanical information on medical plants which provides baseline data for future pharmacological studies and genetic diversity is helpful in selection elite genotypes for future conservation as well as may allow identification of important therapeutic compounds that may be used for the discovery of new drugs. 


\section{Acknowledgment}

The authors are thankful to all the informants of the research area for sharing their knowledge and Department of Genetics Hazara University their Cooperation in SDS-PAGE analyses.

\section{Author's Contribution}

NM collected plants carried out experimental work analyzed the data, NA and NU reviewed the paper and helped in writing the paper and MK helped in in providing chemicals for experiments. All authors have read and approved the final manuscript.

\section{References}

1. Saensouk S (2007) The Family Convolvulaceae in Muang District, Nongkhai province Thailand. KKU Res J 12(3): 237-243.

2. Nagendra PK, Shivamurthy GR, Aradhya SM (2008) Ipomoea aquatica, An Underutilized Green Leafy Vegetable: A Review Int J Botany 4(1): 123-129.

3. Uva RH, Neal JC, Ditomaso JM (1997) Weeds of the Northeast. Ithaca, NY: Cornell University Press, p. 214-217.

4. Khatiwora E, Adsul VB, Kulkarni M, Deshpande NR, Kashalkar RV (2012) Antibacterial activity of Dibutyl Phthalate: A secondary metabolite isolated from Ipomoea carnea stem. J Pharm Res 5(1): 150152.

5. Ruckmani DS, Chitra M, Jaya mathi P (2010) Hepatoprotectivity and an antioxidant study of Ipomoea hederacea on experimentally induced hepatotoxic rats. Recent Research in Science and Technology 2(11):1719.

6. Gleason HA (1963) The New Britton and Brown Illustrated Flora of the Northeastern United

7. McConnaughay KDM, Bazzaz FA (1987) The relationship between gap size and performance of several colonizing annuals. Ecology 68(2): 411-416.

8. Kendall WT (2005) KES Species Distribution List for Township 16 South, Range 12 East, Pima County Arizona. Gila and Salt River Baseline and Meridian.

9. Nisar M, Ghafoor A, Wadood SF, Iqbal A, Nausheen (2016) Intra and inter specific profiling of Pakistani Quercus Species growing in hilly areas of District Dir Khyber Pukhtunkhwa. Pak J bot 48(1): 263-270.

10. Ndiaye M, Faye B, Tine R (2012) Assessment of the Molecular Marker of Plasmodium falciparum Chloroquine Resistance (Pfcrt) in Senegal after Several Years of Chloroquine Withdrawal. Am J Trop Med Hyg 87(4): 640-645.

11. Wadood SF, Hassan N, Khaliq A, Nausheen, Jan T, et al. (2016) Genetic polymorphism in Lens culinaris collected from Malakand division Khayber Pakhtunkhwa, Pakistan. JBES 8(2): 53-60.
12. Pragati VG, Parameshwar, Sreenath KP (2013) Phylogenetic Relationship of Some Ipomoea Seed Proteins by SDS-PAGE. Int Res J Biological Sci 2(10): 64-67.

13. Alexiades MN (1996) Selected Guidelines for Ethnobotanical Research: A Field Manual. The New York Botanical Garden, New York, USA, pp. 99-133.

14. Rawat JMS, Tomar YK, Rawat V (2017) Effect of stratification on seed germination and seedling performance of wild pomegranate. Journal of American Science 6(5): 97-99.

15. Trotter RT, Logan MH (1986) Informant census: A new approach for identifying potentially effective medicinal plants. In: Etkin LN (Ed.), Plants in indigenous medicine and diet. Redgrave, Bedford Hill, New York, USA, pp. 91-112.

16. Uddin MZ, Hassan Rahman MA, Arefin MK (2012) Ethno-medicobotanical study in Lawachara National Park, Bangladesh. Bangladesh J Bot 41(1): 97-104.

17. Mohammed A, Kidanu A, Mohamed A, Asrat P, Abera K, et al. (2011). Dire Dawa Administration Program of Adaptation to Climate Change. DDAEPA. Dire Dawa, Ethiopia.

18. Sadeghi Z, Kuhestani K (2014) Ethnobotany of date palm (Phoenix dactyli-fera) in Baluch tribe of Saravan region, Baluchistan, Iran. Journal of Agricultural Technology 10(6): 1571-1585.

19. Ladio AH, Lozada M, Weigand TM (2007) Comparison of traditional wild plant knowledge between aboriginal communities inhabiting arid and forest environments in Patagonia, Argentina. J Arid Environ 69(4): 695-715.

20. Rakoczy-Trojanowska M, Bolibok H (2004) Characteristics and comparison of three classes of microsatellite-based markers and their application in plants. Cell Mol Biol Lett 9(2): 221-238.

21. Oppong-Konadu EYR, Akromah RK, Adu-Dapaah H, Okai E (2005) Genetic Diversity within Ghanaian Cowpea Germplasm Based on SDSPAGE of Seed Proteins. Afr Crop Sci J 13(2): 117 -123.

22. Ladizinsky G (1979) Species relationship in the genus Lens as indicated by seed-protein electrophoresis. Bot Gaz 140(4): 449-451.

23. Azeez MA, Morkinyo JA (2004) Electrophoretic characterization of crude leaf protein in Lycopersicum and Trichosanthes cultivars. Afr J Biotechnol 3(11): 585-587. Cranbrook Institute of Science.

24. Alkinwusi O, llloh HC (1995) Crude protein electrophoresis of seed of some species of Hibiscus. Nig J Bot 8: 71-76.

25. Das S, Mukherjee KK (1997) Morphological and biochemical investigations on Ipomoea seedlings and their species interrelationships. Ann Bot 79(5): 565-571.

26. Wilkin P (1999) A morphological cladistic analysis of the Ipomoea (Convolvulaceae). Kew Bull 54(4): 853-876. 
Your next submission with Juniper Publishers will reach you the below assets

- Quality Editorial service

- Swift Peer Review

- Reprints availability

- E-prints Service

- Manuscript Podcast for convenient understanding

- Global attainment for your research

- Manuscript accessibility in different formats ( Pdf, E-pub, Full Text, Audio)

- Unceasing customer service

Track the below URL for one-step submission https://juniperpublishers.com/online-submission.php 